\title{
ACCOUNTABILITY OF RECLAME TAX MANAGEMENT IN THE REVENUE DEPARTMENT OF MAKASSAR CITY
}

\author{
Marsuq \\ Universitas 17 Agustus 1945 Samarinda \\ Faculty of Social and Political Sciences \\ INDONESIA \\ Corresponding Author Email: mrsq0959@yahoo.co.id
}

\begin{abstract}
This research will answer four study inquiries including : 1) How is the clarity of the roles and responsibilities of employees in the management of the advertisement tax in the Regional Revenue Office of Makassar?, 2) How is the clarity performance expectations in the management of the reclame tax in the Regional Revenue Office of Makassar?, 3) how is the balance between capacity and expectations of the management of the reclame tax of Revenue Department in Makassar City? 4) How is the reliability of the reclame tax management reports on the Regional Revenue Office of Makassar?. The method used is qualitative descriptive method by collecting data through direct observation techniques, interviews, and documentation. Intake of informants is based on purposive sampling. The process of data analysis include data reduction, data presentation, and conclusion. The results of this research study to answer the research questions above. The first, less optimal division of tasks in the field resulted in the implementation of the accountability of management tasks the reclame tax becomes unclear technically. Second, the fulfillment of the reclame tax revenue target has not been realized to the fullest. Third, there is a proper balance between capacity and expectations, it is characterized by the lack of human resources in terms of quantity and quality. Fourth, reliability reports still do not reflect the real conditions that occur in the field at the same time it shows the achievement of the organization's mission is not optimal, so it can bring the understanding that the management of the reclame tax cannot be said to be accountable in terms of the fulfillment of targets and mission of the organization.
\end{abstract}

Keywords: Accountability, Management, Reclame Tax.

\section{INTRODUCTION}

One of the main principles in realizing good governance is accountability (Rachmat, 2009). In historical perspective, accountability as a system has been known since antiquity Mepsopotamia $4000 \mathrm{BC}$, which at that time was known as Hammurabi's Law which requires a person to account for all of his actions to the authorities (Dunn, 2000). Koppel in his Patahologies of Accountability explained that in order to understand the concept of accountability well, then you need to know what are its dimensions. Koppel said that the dimensions of accountability is basically nothing more than five kinds, namely Transparency, liability, controlability, responsibility and responsiveness, in which each of these dimensions provide an overview and concepts that cover its own self (Sangkala, 2012). In the study of the science of public administration, accountability debate originated from the dialogic debate between Carl Friedrich and Herbert Finer (Denhardt and Denhardt, 2013). In the Journal of Public Policy Friedrich said that "professionalism" or technical expertise is the determining factor accountability of administration. Considering the degree of responsibility is based on 
professionalism and norms of action then the administrator should be accountable for achieving the agreed common standards.

Some of the results of studies that have been conducted by previous researchers in relation to accountability, including (Giyanto, 2013) with a titled thesis Accountability Fund Management School Operational Assistance (BOS) State Primary School Belah I Sub Donorojo, Pacitan, aims to describe the accountability of the management of BOS funds the results showed that the accountability of the management of BOS funds from planning, budgeting in a transparent category, the implementation is done well despite the disbursement of funds is still experiencing delays. Use of funds are transparent, in accordance with the plan set out in the preparation RKAS, reporting is done well, monitoring / supervision by the Supervisory kindergarten and elementary done once a year, while the principal once every three months, showed a transparent and accountable result.

Susi Hambani and Martin Roestamy (2015) with the title management accountability tax on private universities in an effort to implement the principles of good University governance, research was carried out by taking secondary data from various sources, both from the Directorate General of Tax, articles, legal journals, as well as secondary sources other and conducted a survey to some private universities. The results showed that the tax obligations of private universities, withhold, deposit and report tax implemented on behalf of the foundation founders. Accountability requires that the university should be able to account for the whole process of the implementation of the university on all stakeholders, both internal and external, especially in the general population. Therefore, university status which is not subject to tax makes tax management accountability university cannot be reported on behalf of the university, but on behalf of the foundation that shades it.

From the research that has been done, the researchers dig from a different angle namely in terms of management. Particularly accountability in financial management in local government becomes important to be noted considering each region have their respective financial policy in accordance with local regulations. The local fiscal policy geared to increase revenue financial position of the region largely determines the patterns, shapes, and possibilities of activities to be implemented by local governments.

Financial management, especially through the Local Revenue is desired in each region, because the region's financial are rights and obligations. Where the region has the right to seek sources of local revenue in the form of tax levy, retribution or other income sources in accordance with the provisions of the applicable legislation. Then the region has an obligation to spend money in order to implement all areas of government affairs.

Particularly in the city of Makassar, specifically, the financial management of special taxes on the local regulation of Makassar No. 3 Year 2010 on Local Taxes. This regulation shows the authority of the tax collection by the government of the city of Makassar and the results used to finance local government spending in implementing governance and development in the area. Achievement of results rated yet to optimize the achievement of an obstacle that needs to be examined in this study especially those on the management of the reclame tax in Makassar.

Departing from these problems indirectly give a negative stigma to the accountability of the management of the reclame tax in the Regional Revenue Office Makassar while encouraging researchers to explore effective accountability that is directed at indicators clarity of roles and 
responsibilities, performance expectations, balance capacity with expectations, as well as reliability report in accordance with the views Demirel (2014) the next of these indicators will be reflected on who should carry out accountability; to whom he is accountable; What standard is used for the assessment of accountability; and the value of accountability itself Carino in (Sedarmayanti, 2009). It is to be searched by investigators in order to bring up a description and analysis of the accountability of the management of the reclame tax in order to realize the achievement of goals / mission of the organization.

\section{METHODOLOGY}

This research was conducted in the Office of Regional Revenue Office of Makassar. This research approach is qualitative, then this study structured descriptively to identify and describe effective accountability of indicators clarity of roles and responsibilities, performance expectations, balance capacity with expectations, as well as the reliability of the reclame tax management reports Makassar. The informants consist of officials and employees in the Regional Revenue Office of Makassar in particular on informants in the field of reclame. Informant determining technique is purposive sampling. Data collection techniques used in this study are: observation, interviews, and documentation. Then the data were analyzed in this study using a model of Miles and others, where the data were analyzed qualitatively, the data analysis performed interactively and runs continuously until complete. The series of processes include data reduction, data presentation, and data verification. (Sugiyono, 2011). The circuit is used in describing the results of research on management accountability Makassar the reclame tax that would answer the research questions, namely:

1. How is the clarity of roles and responsibilities of employees in the management of the reclame tax of Regional Revenue Office in Makassar City?

2. How Clarity of performance expectations in the management of the reclame tax of Regional Revenue Office in Makassar City?

3. What is the balance between capacity and expectations of the management of the reclame tax of Regional Revenue Office in Makassar City?

4. How is the reliability of the reclame tax management reports on the Regional Revenue Office Makassar?

\section{FINDINGS AND DISCUSSION}

\section{Clarity of roles and responsibilities}

Based on interviews, it can be seen that there is a division of tasks and responsibilities for employees of Regional Revenue Office particularly on the reclame tax contained in the basic tasks and functions that have been assigned but can be obtained a description of other phenomena that occur in the field, is not the division of tasks field where the system works as a partnership between an employee or work group. Furthermore, from the results of interviews, it can be described that the division of duties and the responsibility remains formal and hierarchy as depicted in basic duties and functions, but from the facts found indicate that all the officers working in the technical field to create the rules to be flexible in the sense that an employee may complement each other's work without the division of labor based on each section so that field officers can do everything better data collection, assessment and collection. Furthermore, a dicription obtained that the division of tasks and the responsibility remains formal and hierarchy as depicted in the duties and functions, but from the facts found indicate that all the officers working in the technical field creating the rules become flexible in the sense that employees able to complement the work of the each other without division of labor based on each section so that field officers can do everything 
including data collection, assessment and collection. Based on the interview made clear that the technical review of the field found objects in taxation not in accordance with the existing data collection in the field. This shows that it is difficult to identify who is responsible for the task because of the determination, billing and collection is done jointly or prototype system works without relying on division of duties.

Furthermore, a review of the level of the leadership of the head of reclame tax in general has a duty to coordinate with the heads of agencies related to the implementation; administrative services, data collection, provision, billing reclame tax accounting and reporting. This was stated in the regulations mayor No. 40 of 2009 which provides job descriptions structural position of Regional Revenue Office Makassar. This shows the great responsibility of leadership in the field of reclame tax control all technical terms ranging from administrative services, data collection, assessment, billing until the reclame tax accounting and reporting.

Through several interviews searches, can be obtained an understanding that the division of responsibilities in the management of reclame tax can not be separated from the main duties and functions that have been set on Mayor Regulation No. 100 of 2014 on Description of Duties structural positions on the Regional Revenue Office Makassar. But in its implementation in the field found a phenomenon that is the division of duties becomes raw and made flexible by field staff so that it can make accountability the implementation of management tasks reclame tax becomes the responsibility of all employees in the field of reclame tax regardless of the duties, but in case of serious problems in the field then the responsibility of the head of the field to go down spaciousness. Then the search results roles and responsibilities in the field indicates a number of issues that the review of tax object that does not fit in with the existing data collection in the field. Then the results of the review in terms of data collection do not support taxpayer data base system and a review of the terms of the billing requires improving the quality of human resources that have the mindset and good communication.

Search on the role and the responsibility in technical terms ranging from determination that shows the results of the review of tax object that does not fit in with the existing data collection in the field. Then the results of the review in terms of data collection do not support taxpayer data base system and a review of the terms of the billing requires improving the quality of human resources that have the mindset and good communication. According to Kohler in (Waluyo, 2007) Accountability can be seen as an obligation to prove good management, good control, or a good performance required by applicable law, the provisions (regulation), approval, or that the (custom) have been described from the research concludes that there is a control conducted leadership in case of problems in the field leader in the field of reclame can be dropped directly into the field as a form of accountability though from cunducted review technically still found obstacles both in the technical data collection, assessment and collection, it is associated with the function control leadership in relation to the responsibilities of the management of reclame.

\section{Clarity of performance expectations}

Based on the results of the interview can be seen that the reason the restrictions on the establishment of new billboards is more due to national road policy goals halls set up to not allow their advertisement on a specific road. Despite the fact that the field contained advertesing protesting at the national level and won. Through a variety of exposure data and interviews can be concluded that the follow-up from achievement of the objectives / targets 
cannot be realized maximally, it is reflected by the data showing the number of the target realization reclame tax reached $73.63 \%$ indicating that the achievement of performance expectations have not been met. This is due to restrictions on reclame advertising cigarettes and alcohol, sluggish economic conditions in the last 2 years, as well as restrictions on reclame on certain roads because it can affect the aesthetics of the city became a problem that led to the achievement of the target in the management of reclame tax cannot be maximal in the realization of tax revenue.

In a follow-up indicators of achievement of the objectives / targets reclame tax Regional Revenue Office Makassar, cannot be realized maximally this is reflected by the data showing the number of the target realization reclame tax reached $85.42 \%$ in 2014 and $73.63 \%$ in 2015 means that the achievement performance expectations have not been fulfilled this is due to restrictions on billboards advertising cigarettes and alcohol, sluggish economic conditions in the last 2 years, as well as restrictions on billboards on certain roads because it can affect the aesthetics of the city became a problem that led to the achievement of the target in the management of reclame tax cannot be maximal in the realization of revenue tax. accountability is the fulfillment of a mission that is based on three intervention one is referring to the targets, programs, implementation and evaluation of the specific output is expected. (Benveriste, 1994). The results showed that the fulfillment of the reclame tax revenue target has not been realized maximally so that the clarity of performance expectations can be said not meet the criteria of achieving the mission of the first, namely multiplication of PAD sources optimally.

\section{The balance between capacity and expectations}

Based on the interview can be seen that there is still a lack of human resources owned for data collection and billing matters that is divided per region with a fairly wide area coverage coupled with a lot number of taxpayer implications on the lack of effective data collection and billing the taxpayer because of insufficient numbers of staff involved. Based on several interviews to obtain information that the human resources available are still not conducive to the fulfillment of the expectations or targets revenue sources of taxpayer despite having made efforts sanctioning if the targets per individual officers not met but there are informants said no sanctions that is obtained work without any targets. For the current number of existing human resources to maximize the reclame tax revenue is more supported by more active contract employees took to the field while the incentives are still considered less affecting employee motivation.

Based on the interview it is known that reclame tax officials sometimes do not understand the object of taxation for many types of rules in the form of reclame tax rules so that the necessary socialization to the officer or to the taxpayer and misuse of funds occurs some taxpayers so that those responsible be sanctioned. Based on the interview can be obtained a discription that there are resource constraints equipment used in the management of reclame tax. It is known from their car on rent for the operational needs of signage management. In addition, the use of private vehicles is unavoidable to perform tasks in the field of reclame employees without dependents even though the cost of fuel used. Furthermore, it can be concluded that the balance between capacity and expectation does not happen it is characterized by the lack of human resources assigned to the job specializations billing and collection coupled with the number of taxpayers reclame were not addressed Regional Revenue Office maximally so as to optimize the achievement of the target cannot be met in 
addition to the limitations operating equipment and the lack of incentives contract employees become obstacles in maximizing tax revenue of this reclame.

In this indicator, the balance is not found, it is marked by the lack of human resources assigned to the billing and collection job specialization added with the number of taxpayers that have not been addressed reclame Regional Revenue Office maximally, thus optimizing the achievement of targets cannot be fulfilled. In this study the role of leadership in the field of reclame tax is lack of support in terms of human resources that works technically in the field both in quantity and quality in addition to the incentive contract employees were minimal also affected performance of employees, added with resource tools are still lack supporting in relation to the capacity organization Regional Revenue Office Makassar as agencies from reclame tax in Makassar.

\section{Reliability of Reports}

Report evaluated every three months related to taxpayer data. Development SKPD (Local Tax Decree) as well as the amount of taxpayer who has to pay the reclame tax. In addition to data collection and billing by three months report also contained LAKIP (Report of Performance Accountability of Government) are made each year. At Regional Revenue Office LAKIP portray the performance of agencies that manage local revenues from the tax sector including reclame tax. Measurement gains of 2014 are based on a LAN Decree No. 239 / IX / 6/8/2003 dated March 23, 2003 Guideline of Government Performance Accountability Reporting. Measurement of the gains made by setting performance indicators are inputs, outputs and outcomes (results).

Measurement of the gains made by comparing the performance plan Main program to be achieved with the realization of organizational performance. Further analysis of the causes of the performance gap that occurs as well as the necessary corrective action in the future. This is helpful in giving an overview to external parties about the extent to which an organization has to realize the mission that has been set. Based LAKIP explained that the reclame tax in Fiscal Year 2014 is targeted at Rp.23.248.645.000, - and by the end of fiscal year 2014 realized for Rp.19.859.383.752, - or by $85.42 \%$. This revenue has not been able to reach the target because of increased rates of reclame tax rate of $20 \%$ to $25 \%$ based on Regional Regulation No. 3 of 2010 on Regional Taxes and the lack of effective supervision and control carried out by officers / teams in the field.

When you browse from the LAKIP disclosed the cause of revenue not yet reached the target is the lack of effective supervision and control by the team in the field without having obtained a detailed explanation on the implementation of surveillance and control as to what is meant less effective. Whereas on the search results of interviews conducted earlier in the clarity of expectation performance indicators show that not achieving the target for their reclame tax moratorium banning the establishment of new permanent reclame done in Makassar.

From the various descriptions can be obtained the understanding that the reliability of the reports shown to illustrate the performance and the results achieved have constraints in terms of billing taxpayer that shows a lack of awareness of taxpayers to pay. In the hierarchy of the responsible person is the head of tax on billboards within reclame tax management performance reporting. Overview report is generally depicted in LAKIP but not parse the specific problems causing the ineffectiveness of tax administration performance in the report. 
Indicators reliability of the report aimed to describe the performance and the results achieved have constraints in terms of billing taxpayer that shows a lack of awareness of taxpayers to pay. In the hierarchy of the responsible person is the head of tax on billboards within reclame tax management performance reporting. Overview report is generally depicted in LAKIP but not parse the specific problems causing the ineffectiveness of tax administration performance in the report. Accountability is associated primarily with the mechanism of supervision, reporting, and accountability to a higher authority in a formal chain of command. It is appropriate that Kohler stated in (Waluyo, 2007) Obligations of a person (employee), agent, or other person to give a satisfactory report periodically on the action or the failure to act from authorization or authority owned. Reports made quarterly and annually report appeared in the form of a portrait LAKIP Department's performance in one fiscal year in the report revealed that reclame tax revenue targets are not achieved due to ineffective implementation of the supervision and control of reclame tax of Regional Revenue Office in Makassar City.

Based on the results of the exposure related research management accountability reclame tax in Makassar described through four indicators of effective accountability (Demirel, 2014) can be seen that the indicator Clarity of Roles and Responsibilities shows the division of duties and the responsibility remains formal and hierarchy as described the basic duties and functions set out in the Mayor Regulation No. 100 of 2014 on duties structural positions on the Regional Revenue Office Makassar. but from the facts found indicate that all the officers working in the technical field to create the rules to be flexible in the sense that employees able to complement each other's work without based division of labor in section respectively (system prototype) so that field staff can do everything also data collection, assessment and collection. because the division of duties in the field is not implemented, resulting in accountability for the implementation of reclame tax management task becomes unclear technically because the work is not based on the duties that describes in detail the duties and responsibilities. This means that for the affairs of the determination, data collection, and billing the responsibility of the whole field of reclame tax.

Accountability is an evolution of the activities carried out by an officer whether they are on track authority or already far beyond the responsibility and authority. Carino in (Sedarmayanti, 2009). who should implement accountability; to whom he is accountable; What standard is used for the assessment of accountability; and the value of accountability itself. That implement accountability in the management of reclame tax are department heads and staff that responsible to the department head when viewed from the structure hierarchy while for the assessment standard refers to the set target. Accountability has value to further improve the performance of the management of reclame of various technical aspects of data collection, provision, and billing to the achievement of regional revenue from reclame field can be in a more optimal level.

Finally, the overall indicator of effective accountability in this study illustrates that the ineffectiveness of the the division of duties in the field, resulting in accountability for the implementation of reclame tax management task becomes unclear technically. fulfillment of reclame tax revenue target has not been realized maximally so that phase to target the performance expectations can be said to be an unmet optimally yet it also shows the optimal achievement of the organization's mission. (Rachmat, 2009) which concluded that accountability is the obligation of a person or an organizational unit accountable for the management and control of resources and implementation of policies entrusted to him in order to achieve the goals set. Objectives set includes the organization's mission that is 
exploring sources of PAD optimally, has not been met because the target cannot be achieved and the mission and to enhance management systems PAD is plagued with system data base that needs to be repaired, then the mission to improve the ability of Resources humans cannot be reflected in this study because it still requires human resources that have good individual capacity, especially in communicating with the taxpayer. This has led to the understanding that the management of reclame tax cannot be said to be accountable for the fulfillment of targets and mission of the organization.

\section{CONCLUSION}

Overall indicators of accountability in this study illustrates that the ineffectiveness of the field resulted in the division of duties accountability execution of management tasks reclame tax becomes unclear technically. fulfillment of reclame tax revenue target has not been realized maximally so that phase to target the performance expectations can be said to be unmet optimally because found a variety of technical and human resource constraints, improper balance happened between capacity and expectations. It is characterized by the lack of human resources in terms of quantity and quality, the reliability indicators report is still not reflecting the real conditions that occur in the field. This also shows yet optimal achieving the mission so that it can raise understanding that the management of reclame tax cannot be said to be accountable in terms of the fulfillment of targets and mission of the organization. From this research, it is suggested repairing and revamping the technical terms, especially in terms of data Base Taxpayers who used to be integrated with a system of tax management obviously need tools and technologies that support and increase the quality and quantity of human resources through training to be given it is necessary that shortage human resources can be covered temporarily by increasing the capacity and performance of employees in terms of understanding the rules of reclame tax and improve communication patterns with taxpayer.

\section{REFERENCES}

Denhardt, J.V. \& Denhardt, R.B. (2013). Pelayanan Publik Baru Dari Manajemen Steering ke Serving. Bantul : Kreasi Wacana.

Demirel, D. (2014). Accountability and the Changing Function af the control. Nigne Universitesi : Yonitim Bilimleri Dergesi.

Dunn, W.N. (2000), Analisa Kebijakan Publik, Yogyakarta, Gajah Mada University Press. Giyanto. (2013). Akuntabilitas Pengelolaan Dana Bantuan Operasional Sekolah (BOS) di SD Negeri Belah I Kecamatan Donorojo, Kabupaten Pacitan. Universitas Muhammadiyah : Surakarta.

Benveriste, G. (1994), Birokrasi, Jakarta: Rajawali Pers.

Hambani, S. \& Roestamy, M. (2015). Akuntabilitas pengelolaan pajak pada universitas swasta dalam upaya penerapan prinsip-prinsip good University governance. Universitas Juanda: Bogor

Rakhmat. (2009). Teori Administrasi dan Manajemen Publik. Banten: Pustaka Arif. Sangkala. (2012). Dimensi-dimensi Manajemen Publik. Yogyakarta: Penerbit Ombak Sedarmayanti. (2009). Manajemen Sumber Daya Manusia Reformasi Birokrasi dan Manajemen Pegawai Negeri Sipil. Bandung: Rafika Aditama

Sugiyono. (2011). Metode Penelitian Kombinasi (mixed methods). Bandung: Alfabeta. Waluyo. (2007). Manajemen Publlik (konsep, aplikasi dan implementasinya dalam pelaksanaan Otonomi Daerah). Bandung: Mandar Maju. 